Journal of Biotechnology and Strategic Health Research

Derleme / Review

http://dergipark.org.tr/tr/pub/bshr

\title{
Hasta ve Yakınlarının Eğitiminde COVID-19: Hemşireler Ne Anlatmalı?
}

\author{
Education of Patients and Their Relatives About COVID-19: What Should Nurses Tell?
}

(iD) Özlem Bilik

Dokuz Eylül Üniversitesi Hemşirelik Fakültesi Cerrahi Hastalıkları Hemşireliği Anabilim Dalı, İzmir

ORCID ID: Özlem Bilik https://orcid.org/0000-0002-8372-8974

*Sorumlu Yazar / Corresponding Author: Doç. Dr. Özlem Bilik, e-posta / e-mail: ozlembilik71@gmail.com

Geliş Tarihi / Received : 15-05-2020 Kabul Tarihi / Accepted: 19-05-2020 Yayın Tarihi / Online Published: 31-08-2020

Bilik Ö. Hasta ve Yakınlarının Eğitiminde COVID-19: Hemşireler Ne Anlatmalı?

J Biotechnol and Strategic Health Res. 2020;4(2):78-88

$\ddot{O} z$

Günümüzün küresel felaketi haline gelen COVID-19 yaşamsal önem arz etmesi nedeniyle sağlık sorunları içinde ilk sıraya geçerek insanların davranış biçimlerini ve sağlık bakım gereksinimlerini önemli derecede etkilemiştir. Toplumdaki bireyleri enfeksiyondan korumak ve COVID-19 şüphesi olan ya da tanısı doğrulanmış bireylerin enfeksiyonu yaymasını önlemek için hasta ve yakınlarının COVID-19 hakkında bilgilendirilmesi, eğitici rolü açısından hemşirelere önemli sorumluluklar yüklemektedir. Hastanın bakımından sorumlu olan hemşirelerin hem hastalara hem de aynı zamanda toplumun sağlıklı bireyleri olan hasta yakınlarına eğitim vermesi gerekmektedir. Bu gereksinimden yola çıarak yazılan bu derleme güncel rehberler doğrultusunda hazırlanmıştır.

Anahtar COVID-19, Hasta ve Yakınlarının Eğitimi, Hemşirelik

Kelimeler

Abstract

COVID-19, which has become a global disaster of today, has taken a first place in the health problems due to its vital importance and has significantly affected people's behaviors and health care needs. Education of patients and their relatives about COVID-19 in order to protect individuals in the community from infection and prevent individuals with suspected or confirmed diagnosis of COVID-19 imposes significant responsibilities on nurses in terms of their educational role. Nurses who are responsible for the patient's care need to provide education to both patients and their relatives who are healthy individuals of the society. Based on this requirement, this review has been prepared throught current guidelines.

Keywords COVID-19, Education of Patients and Their Relatives, Nursing 


\section{GIIRIŞ}

Çin'in Wuhan kentinde Aralık 2019 tarihinde nedeni açıklanamayan pnömoni vakaları sonucunda yeni tip bir koronavirüsün insandan insana bulaşının olduğu ortaya çıkarılmıştır. ${ }^{1}$ Koronavirüs hastalığı 2019 (COVID-19) pandemisi, SARS-CoV-2'nin neden olduğu bir enfeksiyondur. 29 Şubat tarihine kadar dünya genelinde 73332 vaka olup, bunların 72 528'i Çin'de görülmüş ve 1870'i ölümle sonuçlanmıştır. Yine aynı tarihte salgının Çin dışında 25 ülkeye yayıldığı ve 3 kişinin ölümüne neden olduğu bildirilmiştir. ${ }^{2}$ Dünya Sağlık Örgütü (World Health Organization-WHO) 13 Mayıs 2020 tarihinde güncellediği bilgilerde dünya genelinde 4170424 vaka görüldüğünü, son 24 saat içindeki yeni vaka sayısının 81577 olduğunu, hastalığa bağlı şimdiye kadar 287399 ölüm görüldüğünü ve son 24 saatte yaşanan ölüm sayısının 4245 olduğunu belirtmiştir. ${ }^{3}$ Ülkemizde ilk vaka 11 Mart 2020'de ortaya çıkmıştır. ${ }^{4-5} 13$ Mayıs 2020 tarihine kadar Türkiye'de toplam 141475 vakaya tanı konduğu, 3894 ölüm gerçekleştiği, aynı tarih itibariyle yeni vaka sayısı 1704 iken ölüm sayısının 54 olduğu bildirilmiştir. ${ }^{3}$ Rakamlardan da görüldüğü gibi virüs çok hızlı yayılmaktadır. Bu nedenle enfekte insanların karantinaya alınması, taramaların artırılması, sosyal mesafe sınırı konması ve seyahatlerin kısıtlanması gibi önleyici tedbirler küresel boyutta uygulanmaya başlanmıştır.,

Hastalık oluşturma süreci farklı seyredebilen virüsün her kişideki etkileri de değişkenlik göstermektedir. Enfekte olan bazı bireylerde hastalık belirtileri hiç görülmeyebildiği gibi, bazı kişilerde semptomlar hafif şekilde görülmekte, bazılarında ise hastaneye yatışı gerektirmektedir. ${ }^{6}$ Acil servislere başvuran hastaların birçoğunda COVID-19 şüphesi oluşturan kuru öksürük, ateş ve nefes darlığı şeklindeki üçlü semptom ön planda olup; hastalığın hafif ya da ciddi olmasına göre baş ağrısı, boğaz ağrısı, kas ağrısı, tat ve koku almada bozulma, halsizlik, iştahsızlık, üşüme ve titreme, ishal, taşipne, hipoksi ve pnömoni gibi bulgular da görülebilmektedir., ${ }^{4,6,8} \mathrm{Bu}$ belirtiler nedeniyle hastaneye başvuran hastalardan nazofarenksten alınan sürüntü örneği incelenmekte, hatalı örnek alma potansiyeli nedeniyle PCR testi yönteminde zaman zaman sıkıntılar oluşabilmektedir. Hızlı antikor test sonucunun 7-10 gün içinde çok daha anlamlı olması ve yaygın kullanılmaması nedeniyle ayırt edici tanılamada klinik bulgular ve gögüs BT kullanılmaktadır. ${ }^{6}$ Yapılan tanılamada hastalık bulgusu negatif olarak değerlendirilen, risk faktörleri bulunmayan ve radyolojik görüntülemesi normal olan hastalar ayaktan takip edilmektedir. Bu durumda bireylerin 14 gün gün izole edilmesi ve PCR testinin tekrarlanması gerekmektedir. Yaş dişında risk kategorilerinden en az bir tanesi var olduğunda bireyin hastane ortamında takip ve tedavi edilmesi uygundur. Başta ARDS olmak üzere hastalık seyrinde kötüleşme olduğunda hastaların yoğun bakıma yatış endikasyonu bulunmaktadır. ${ }^{9}$

Pandemi, özellikle enfeksiyon kontrolü ve hastalık tedavisinde sağlık sistemi için birçok zorluk oluşturmaktadır. ${ }^{10}$ $\mathrm{Bu}$ nedenle yaşlı, diyabetik, kanser, kalp rahatsızlığ 1 olan hastalar gibi riskli gruplar dişındaki hastalar için gerektiğinde öncelik belirlemenin yapılmasına gereksinim duyulabileceği belirtilmiştir. Hafif hastalığı olanlarda hastanın durumunda hızlı bozulma endişesi olmadığı sürece hastaneye yatış gerekli olmayabilir. Bu hasta grubunun evde bakımı sağlanarak hasta aile üyeleri tarafından takipleri yapılabilir. Evde bakım, hastanın hastanede yatarak tedavisinin yapılamadığı veya güvenli olmadığı durumlarda da (kapasite sınırlı olabilir ve kaynaklar sağlık hizmetlerine olan talebi karşılayamıyor olabilir vb.) düşünülebilir. Sağlık kuruluşlarında izole edilemeyen tüm hafif vakalar, hafif hastalığı olanlar ve risk faktörü olmayanlar; özel tasarlanmış oteller, stadyumlar veya spor salonları gibi alanlarda COVID-19 virüs semptomları giderilinceye ve laboratuvar testleri negatif oluncaya kadar izole edilirler. Alternatif olarak, hafif hastalığı olanlar ve hiç risk faktörleri bulunmayanlar evde yönetilebilir. ${ }^{11}$ Bu noktada hastaların ve yakınlarının taburculuk için hazırlanması enfeksiyonun diğer aile üyelerine ve çevreye yayılımının önlenmesi açısından son derece gereklidir. Bu amaçla WHO, hafif semptomlarla hastaneye başvuran şüpheli COVID-19 hastalarının evde bakımı ve toplum sağlığını korumak 
için onların temasta bulunduğu kişilerin alması gereken önlemlere yönelik ihtiyaç duyulan önerileri içeren geçici bir kılavuz geliştirmiştir. ${ }^{11}$ Benzer şekilde Hastalıkları Önleme Merkezi (Center of Diseases Control-CDC) toplumu bilgilendirmek için çeşitli kılavuzlar hazırlayarak web sitesinde yayınlamıştır. ${ }^{12,13,14,15}$ Ülkemizde de Sağlık Bakanlığ 14 Nisan 2020 tarihli COVID-19 kılavuzunu yayınlayarak, sağlık çalışanlarının ve toplumun bilgilendirmesini sağlamıştır . Bu kılavuzlar doğrultusunda hastanın bakımı$\mathrm{n} ı$ üstelenen hemşirelerin uygulayacağı eğitim; virüsün yayılması, izolasyonun önemi, hastanın birlikte yaşadığı aile üyelerinin kendisini nasıl koruyacağı, alınması gereken standart önlemler, evin temizliği ve dezenfeksiyonu, hastaya bakım verenlerin dikkat edeceği noktalar ve stres yönetimi gibi konulara odaklanmalıdır.

\section{Virüsün yayılması}

Şu anda COVID-19 hakkında bilinenlere dayanarak, bu virüsün kişiden kişiye yayılması en sık yakın temaslar arasında olmaktadır. Bu tip bulaşma fomitlerden (mikrobik enfeksiyonları taşıyabilen cansız nesne) ziyade zoonotik solunum damlacıkları yoluyla çok daha sık görülür., ${ }^{4,5,13}$ Enfekte olan ancak semptomları olmayan kişilerin de COVID-19'un yayılmasında rol oynadığı belirtilmiștir. ${ }^{13}$ Virüsü taşıyan insanlar enfeksiyonu öksürerek, hapşırarak ya da öpüşerek yakın temasta oldukları kişilere hava yolu damlacıkları yoluyla aktarabilirler, bu nedenle enfekte eş ya da aile üyelerinin bu aktivitelerinden kaçınmak gerekmektedir. ${ }^{12,16}$ Öksürürken veya hapşırırken ağzın ve burnun bir mendille kapatılması, mendil ya da kağıt havlu yoksa dirsek içine öksürülmesi veya hapşırılması ve bu esnada ellerin kullanılmaması, kullanılmış mendillerin içinde torbası olan bir çöp kutusuna atılması ve ellerin hemen sabun ve su ile 20 saniye yıkanması veya el dezenfektanı kullanılması önerilmektedir. ${ }^{4,12,17,18}$ Ayrıca ishal, soğuk algınlığı, ateş gibi herhangi bir enfeksiyon bulgusu gözlemlendiğinde temastan kaçınılması ve bu kişilerin izole edilmesi önemlidir. Bunun yanı sıra hasta kişi mümkün olduğunca marketlere ya da halka açık yerlere gitmemelidir. Korona virüsü kedi, köpek domuz, inek, hindi gibi evcil hayvan- lardan da bulaşabilir. Canlı ya da ölü hayvanların olduğu pazarlara gitmekten, hayvanlarla ve onların dışkıları ile temastan kaçınılmalıdır. Henüz aşısı ve tedavisi geliştirilemediği için, sosyal yaşam içinde mesafe koymak yaşamsal öneme sahiptir. ${ }^{16}$ İnsanların gruplar halinde toplanmamas1, market ve pazar gibi toplumsal alanlara girmek zorunda kaldığında sosyal mesafeyi koruması gerekmektedir. Bunun için önerilen sosyal mesafe sınırı yaklaşık 1.8 metredir (iki kol uzunluğu kadar-6 fit). ${ }^{12}$ Bir diğer önemli konu kişilerde enfeksiyon belirtisi olmasa dahi enfeksiyonu yayma potansiyeli olduğu için maske takma zorunluluğudur. $\mathrm{Bu}$ nedenle 2 yaş altındaki çocuklar, ciddi nefes alma zorluğu olanlar ve tek başına maskeyi çıkaramayacak olanlar d1şında herkes, toplumsal alana çıkmak zorunda kaldığında mutlaka maske kullanmalıdır. Bu bağlamda dikkat edilecek noktalardan biri, kişilerin sağlık çalışanları için tasarlanmış maskeleri kullanmamasıdır. ${ }^{12}$ Hastalık tanısı konan ya da şüphesi olan kişinin evde ve doktor kontrolüne giderken mutlaka maske takması gerekmektedir. Hastaya bakım veren kişi hastanın odasına girerken mutlaka maske takmalı, hastadan da maske takmasını istemelidir. Maskenin olmadığı durumlarda sağlık çalışanı dışındaki kişiler eşarp ya da bandana kullanarak ağız ve burnunu kapatabilir. ${ }^{19}$ Öte yandan, yeni koronavirüsün virüsle kontamine olmuş yüzeylerden kişilere geçtiği kesin olarak belgelenmemiştir. ${ }^{13}$ Yine de virüsün çeşitli malzemelerden yapılmış yüzeylerde uzun süre yaşayabileceği unutulmamalıdır. Virüsün kağıtta ve tuvalet kağıdında 3 saate kadar, tahta ve bez özelliği olan yüzeylerde 2 güne, camda ve kağıt parada 4 güne, paslanmaz çelik ve plastikte ise 7 güne kadar aktif kalabildiği belirtilmiştir. Virüsün sert yüzeylerde uzun süre enfektif kalamadığı, yumuşak ve pürüzlü yüzeylerde sert yüzeylere göre daha stabil olduğu bildirilmiştir. ${ }^{5}$ Enfekte yüzeylere temas eden kişilerin ellerini kendi ya da bir başkasının yüzüne, gözüne veya ağzına değdirmesi risk oluşturmaktadır. Bu nedenle görünür şekilde kirli yüzeylerin temizlenmesi ve ardından dezenfeksiyonu, evlerde ve toplum ortamlarında COVID-19 ve diğer viral solunum yolu hastalıklarının önlenmesi için en iyi uygulama önlemidir. ${ }^{5,12,13}$ 
COVID-19 tanısı doğrulanmış birinin bulunduğu bir odadaki havanın ne kadar bulaşıcı olduğu bilinmemektedir. Kurumların, odaların veya hasta kişiler tarafından daha önce kullanılan alanların ne kadar süre kapatılacağına ya da hastaların kullandığı alanların dezenfeksiyonuna karar verirken; odanın büyüklüğü ve havalandırma sistemi tasarımı (saat başı değişimlerle birlikte hava akış hızı, hava giriş ve çıkış deliklerinin yerleri vb. özellikler) gibi faktörlerin dikkate alınması gerekecektir. COVID-19 hastası olan veya hasta olduğundan şüphelenilen bir kişinin bulunduğu alandaki veya odadaki havalandırmayı iyileştirmek için önlemlerin alınması, solunum damlacıklarının havadan çıkarılma süresini kısaltmaya yardımcı olacaktır. ${ }^{13} \mathrm{Bu}$ nedenle mümkün olduğunca pencerelerin açılması ve oda içindeki hava sirkülasyonunun arttırılması önerilmektedir. Oda içindeki ventilasyonun iyi olması, havada bulunan solunum damlacıklarının giderilmesini kolaylaştıracaktır. ${ }^{19}$ Virüsün klimalardan yayılıp yayılmadığı konusu net olmamakla birlikte, bu konuda yapılan bir çalışmada konuya ilişkin deneysel çalışma eksikliği olduğu ve havalandırmaların iyileştirilmesine yönelik önerilerde bulunduğu görülmüştür. ${ }^{20}$ Ayrıca aynı evde yaşayan bireyler sağlıklı olsa dahi ziyaretçilerin kısıtlanması, özellikle hastalık açısından yüksek risk taşıyan kişilerin ziyaret edilmemesi ve COVID-19 şüphesi olan/tanı konan kişinin olduğu eve ziyaretçi alınmaması önerilmektedir. Ev halkı, hasta olan kişi ile eşyaları asla ortak kullanmamalıdır. Tabaklar, fincanlar, bardaklar, gümüş takımlar, havlular, yatak takımları ya da elektronik cihazlar mutlaka ayrılmalıdır. Hastaya bakım veren kişi kendisinin hasta olmasını önlemek için, günlük önleyici eylemleri uyguladığından emin olmalıdır. Bunun için ellerini sık sık yıkamalı; gözlerine, burnuna ve ağzına yıkanmamış ellerle dokunmaktan kaçınmalı; yüzeyleri sık sık temizlemeli ve dezenfekte etmelidir. ${ }^{19}$

COVID-19 şüphesi/tanısı olan hastaların evde izlem sürecinde evin temizliği ve dezenfeksiyonu önemli bir konudur. Hastanın enfeksiyonu yayma riski devam ediyor olabileceği için hasta taburcu edildikten sonra ayrı bir odada izole edilmelidir. Özellikle evde yaşayan diğer aile üyelerinin korunması için temizliğin ve dezenfeksiyonun standardize olması gerekmektedir. ${ }^{19}$

COVID-19 olduğundan şüphelenilen/ tanı konan ve izole edilmiş olan kişi ile birlikte yaşayan aile üyelerinin evde bakımda temizlik ve dezenfeksiyona ilişkin genel öneriler

- $\quad$ Aile üyeleri, COVID-19 semptomları hakkında kendilerini eğitmeli ve COVID-19'un evlere yayılmasını önlemelidir.

- $\quad$ Aile üyeleri, COVID-19 şüphesi olan / tanı konan kişiler ve izolasyon odaları / banyoları ile etkileşim kurarken evde bakım kılavuzuna uymalıdır.

- Hasta bakımı mümkün olduğunca ayrı bir odada, evde bakım rehberliği izlenerek ve evdeki diğer insanlardan uzak durularak yapılmalıdır.

- Evin ortak kullanım alanlarında yüksek temaslı yüzeyler günlük olarak temizlenmeli ve dezenfekte edilmelidir [örneğin; masalar, sandalyeler, kapı kolları, ışık anahtarları, telefonlar, tabletler, dokunmatik ekranlar, uzaktan kumandalar, klavyeler, tutamaklar, kulplar, tuvaletler, musluklar, lavabolar ve elektronik cihazlar vb. (elektronik cihazların temizlik ve dezenfeksiyon talimatları için aşağıdaki açıklamalara bakınız)]. Ev temizlik ürünlerinin talimatları izlenerek yüzeye uygun rutin temizlik uygulanabilir. Ürün etiketlerinde eldiven giyme, ürünün kullanımı sırasında iyi bir havalandırmayı sağlama, ürünü uygularken alınması gereken önlemler gibi temizlik ürününün güvenli ve etkili kullanımı için gerekli talimatlar bulunmaktadır. Birçok ürün mikropları öldürmek için yüzeyin birkaç dakika ıslak tutulmasını, birçoğu da ayrıca eldiven takılmasını, ortamdaki hava akışının iyi olmasını ve kullanımdan sonra ürünün silinmesini veya durulanmasını önermektedir.

- Hasta bir kişiye özel ayrılmış yatak odasında / banyoda hasta ile gereksiz teması (örneğin kirli eşyalar ve yüzeyler) önlemek için temizlik gereksinimine göre temizleme sıklığı belirlenmelidir. Gereksiz yere hastaya özel oda ve banyoya girilmemelidir.

- Hasta olan kişinin yatak odası ve banyosu mümkünse 
ayrılmalıdır. Mümkün olduğunca hasta olan kişi evde diğer kişilerden ayrı bir yerde kalmalıdır.

- Ayrı bir yatak odası ve banyonuz varsa: İhtiyaç duyulduğunda örneğin hasta olan kişinin çevresindeki alanın kirlenmesi durumunda, hastanın sadece etrafındaki alan temizlenmelidir. Bu hasta kişiyle olan temasın sınırlandırılmasına yardımcı olacaktır.

- Hastaya bakım verenler bakım sırasında kağıt mendil, kağıt havlu, temizlik ürünleri ve dezenfektanlar gibi hastaya özel kişisel temizlik malzemelerini kullanabilir. Eğer hasta olan kişi kendini iyi hissediyorsa, kendi alanını kendisi temizleyebilir.

- Hastaya bakım veren kişi, hastanın odasını ve banyosunu temizlemek için kullanacağı mendil, kağıt havlu, temizlik ürünleri ve dezenfektanlar gibi malzemeleri ayrı bir odada saklamalı, bu odaya çocukların ve diğer kişilerin girmesini engellemelidir.

- $\quad$ Eğer banyo ortak ise: Hasta olan kişinin her kullanımindan sonra banyo temizlenmeli ve dezenfekte edilmelidir. Bu mümkün değilse bakım verenler, banyo temizlenmeden ve dezenfekte edilmeden önce yeterince uzun süre beklemelidir. ${ }^{12,13}$

\section{Yüzeylerin temizliği ve dezenfeksiyonu}

Pandemi ortaya çıktığından beri insanların en çok merak ettiği sorulardan birisi "Yüksek temas yüzeylerini ve yumuşak yüzeyleri nasıl temizleriz ve dezenfekte ederiz?” sorusudur. Her şeyden önce temizlik ve dezenfeksiyonu yapacak olan kişinin tek kullanımlık eldiven giymesi gerekir. Her temizlikten ve dezenfeksiyondan sonra eldivenler atılmalıdır. Çok kullanımlık eldivenler tercih edildiyse, bu eldivenler COVID-19 yüzeylerinin temizlenmesi ve dezenfeksiyonu için tahsis edilmeli ve başka amaçlarla kullanılmamalıdır. Kullanılan temizlik ve dezenfeksiyon ürünleri için üreticinin talimatlarına bakılmalıdır. Eldivenler çıkarıldıktan hemen sonra eller hemen yıkanmalıdır.

Temizlik: Sık temas edilen yüzeylerin rutin temizliği sabun ve su kullanılarak yapılmalıdır. Ev ortamında yüksek temas yüzeyleri arasında masalar, kapı kolları, ışık anahtar- ları, tezgahlar, kulplar, çalışma masaları, telefonlar, klavyeler, tuvaletler, musluklar, lavabolar vb. bulunmaktadır. Gözlenebilir kontaminasyon varsa halı, kilim ve perde gibi yumuşak yüzeylerin temizliği önerilmektedir. Bu amaçla sabun ve su ya da kullanıma uygun temizleyiciler kullanılabilir. Eşyaları (mümkünse) üreticinin talimatlarına göre yıkamak gerekir. En uygun sıcaklıktaki su ayarını kullanmak ve tamamen kurutmak diğer önemli unsurlardır.

Dezenfeksiyon: Evlerdeki herhangi bir yüzey veya ürün kirliyse, dezenfeksiyon öncesinde sabun ve su ile veya deterjanla temizlenmelidir. Bu noktada ev dezenfeksiyonu için tescilli dezenfektanların kullanımı önerilmektedir. Ürünün etkili ve güvenli kullanımı için etiketteki talimatların (konsantrasyon, uygulama yöntemi ve temas süresi vb.) izlenmesi diğer bir öneridir. Yüzeyi bir süre sslak tutmak gerekir (bunun için ürün etiketine bakılmalıdır). $\mathrm{Bu}$ sürenin ne kadar olacağı üretici firmanın önerisi doğrultusunda planlanmalıdır. Eldiven giyme gibi önlemlerin alınması ve ürünün kullanımı sırasında havalandırmanın iyi olduğundan emin olunması gerekir. Yüzey için uygunsa seyreltilmiş ev tipi çamaşır suyu çözeltileri de kullanılabilir. Ürünün son kullanma tarihinin geçip geçmediği kontrol edilmelidir. Uygun şekilde seyreltildiğinde evdeki herhangi bir çamaşır suyu koronavirüse karşı etkili olacaktır. Uygulama ve uygun havalandırma için üreticinin talimatlarını izlemek gerekir. Ev tipi çamaşır suyu amonyak veya herhangi bir başka temizleyiciyle asla karıştırılmamalıdır. Diğer bir önemli nokta da solüsyonun en az 1 dakika yüzeyde bırakılmasıdır. Seyreltilmiş bir çözelti yapmak için bir galon suya (3.78 litre) 5 yemek kaşığı (1/3 bardak) çamaşır suyu eklemek yeterli olacaktır. Dörtte bir su içine 4 çay kaşı̆̆ı çamaşır suyu koyarak da seyreltilmiş çözelti elde edilmektedir. Diğer bir seçenek de en az \% 70 alkol içeren alkol çözeltilerini kullanmaktır. Yumuşak yüzeylerin dezenfeksiyonunda ev dezenfeksiyonu için tescilli dezenfektanları ile dezenfeksiyon yapılmalıdır. ${ }^{13,19,21}$

\section{Elektronik cihazların temizliği ve dezenfeksiyonu}

Tabletler, dokunmatik ekranlar, klavyeler ve uzaktan ku- 
mandalar gibi elektronik cihazlar için gözlenebilir bir kontaminasyon varsa giderilmesi ve elektronik cihaz üzerine silinebilir bir kapak konması önerilmektedir. Temizlik ve dezenfeksiyon için üreticinin talimatlarını izlemek gerekir. Üretici firmanın herhangi bir yönlendirmesi yoksa, alkol bazlı mendiller veya en az \%70 alkol içeren spreyler kullanılabilir. Daha sonra sıvıların birikmesini önlemek için yüzeyler iyice kurulanır. ${ }^{13,19,21}$

\section{Çamaşırlar (Çarşaflar, giysiler ve çamaşırhaneye giden her türlü eşyalar)}

Çamaşırları (Giysiler, havlular, çarşaflar vb.) ve diğer ürünleri üreticinin talimatlarına göre yıkamak gerekir. En uygun sıcaklıktaki su ayarının kullanılması ve tamamen kurutulması önerilmektedir. Hasta bir kişinin kirli çamaşırlarını tutarken tek kullanımlık eldiven giyilmeli ve kullanıldıktan sonra atılmalıdır. Yeniden kullanılabilir eldivenler kullanılıyorsa, bu eldivenler COVID-19'a yönelik yüzeylerin temizlenmesi ve dezenfeksiyonu için tahsis edilmeli ve diğer ev temizliği ya da dezenfeksiyonu amacıyla kullanılmamalıdır. Hasta olan bir kişinin kirli çamaşırları, diğer insanların çamaşırlarıyla yıkanabilir. Virüsün havada dağılımını en aza indirgemek için kirli çamaşırları silkelememeye özen göstermek gerekir. Çamaşır sepetlerinin yukarıda belirtildiği gibi yüzeyler için olan kılavuza göre temizlenmesi ve dezenfekte edilmesi önerilmektedir. Mümkünse çamaşır sepetinin içine tek kullanımlık ya da yıkanabilir sepet astarı yerleştirilmelidir. Daha sonra eldivenler çıkarılıp eller hemen yıkanmalıdır. Hastanın kullandığ kirli çamaşırlar eldivensiz tutulduysa eller mutlaka yıkanmalıdır. Çamaşırlar yıkandıktan sonra sıcak havada kurutulmalı ya da kurutma makinesi kullanılmalı, çamaşırlar kurutma makinesine konduktan sonra eller yıkanmalıdır. ${ }^{13,19,21}$

\section{Ellerin sık sık yıkanması}

Ellerin sık sık su ve sabunla 20 saniye yıkanması son derece önemlidir. Eldivenleri çıkardıktan sonra ve hasta olan biriyle temas ettikten sonra ellerin mutlaka ve hemen y1kanması gerekmektedir. El yıkamada su ve sabun ya da el dezenfektanı kullanılması önerilmektedir. ${ }^{4,21}$

Sabun ve su yoksa ve eller görünür şekilde kirli değilse, en az \%60 alkol içeren bir el dezenfektanı kullanılmalıdır. El dezenfektanı, ellerin tüm yüzeyine değecek şekilde ve eller ovalanarak kullanılmalıdır. Ancak eller görünür şekilde kirliyse, ellerin her zaman su ve sabunla yıkanması gerekmektedir. ${ }^{19}$ Birisi nefesini üfledikten sonra, öksürdügünde veya hapşırdıktan sonra; tuvalete girmeden önce ve tuvaleti kullandıktan sonra, yemek yemeden veya yemek hazırlamadan önce, yayvan veya evcil hayvanlarla temastan sonra, yardıma ihtiyacı olan başka bir kişinin (örneğin bir çocuk) rutin bakımından önce ve sonra eller yeniden yıkanmalıdır.

Yıkanmamış kirli ellerle yüze, gözlere ve ağza asla dokunulmamalıdır. Yüze dokunulduğunda eller mutlaka su ve sabunla yıkanmalıdır. COVID-19 şüphesi olan ya da tanısı konan bireyle aynı evi paylaşan aile üyeleri ya da arkadaşları, işyerinde ve evdeyken el hijyeni dahil olmak üzere önerilen önleyici eylemleri izlemelidir. ${ }^{13,17,18,19,21}$

\section{Yiyecek}

Hasta olan kişinin beslenme sırasında ayrı kalması, mümkünse kendi odasında yemek yemesi ya da beslenmesi önerilmektedir. Tek kullanımlık olmayan yemek servisi malzemeleri (kaşık, çatal, bıçak, bardak gibi) eldivenle kullanılmalıdır. Bulaşıklar, tabak ve mutfak eşyaları eldiven ve sıcak su kullanarak yıkanmalıdır: Kullanılmış bulaşıkları, fincanları, bardakları veya gümüş takımları eldiven ile tutmak gerekir. Bulaşıklar, sabun ve sıcak su ile veya bulaşık makinesinde yıkanmalıdır. Eldivenler çıkarıldıktan sonra veya kullanılmış yemek servisi malzemeleri ya da eşyaları tutulduktan sonra eller yıkanmalıdır. ${ }^{13,19}$

\section{Çöp}

Mümkünse, hasta olan kişi için belirli bir çöp kutusu belirlemek gerekir. İçine çöp torbası geçirilmiş çöp kutusunun kullanımı önerilmektedir. Kullanılmış tek kullanımlık eldivenler, maskeler ve diğer kontamine ürünler çöp tor- 
basına atılmalıdır. Çöp torbalarını çöp kutusundan çıkarırken, çöpleri tutarken, taşırken ve çöpe atarken eldiven kullanılmalıdır. Daha sonra eller yıkanmalıdır. Hasta kişinin kanına, dışkısına veya tükürük, mukus, kusma ve idrar gibi vücut sıvılarına temas riskine karşı hastaya bakım verirken mutlaka eldiven giyilmeli, bakım sonlandığında bu eldivenler çöp torbası olan çöp sepetine atılmalı ve eller hemen yıkanmalıdır. Mümkünse çöp imha kılavuzu hakkında yerel sağlık departmanına danışılmalıdır. ${ }^{19,21}$

\section{Sağlık durumunun izlenmesi}

Hastaya bakım verenler dijital termometre kullanımını öğrenmeli ve periyodik olarak hastanın vücut ısısını ölçmelidir. Aynı zamanda kendi sağlık durumunu da yakından izlemeli ve başta ateş, öksürük ve nefes alma zorluğu olmak üzere hastalık belirtilerine karşı dikkatli olmalıdır. Ciddi solunum probleminin olması tıbbi yardım isteme açısından önemli bir bulgudur. ${ }^{19}$

\section{Karantina ve izolasyon}

Toplumda yaşayan bireylere karantina ve izolasyon arasındaki farkı belirtmek gerekir. Karantina; COVID-19 şüphesi olan insanları toplumdaki diğer kişilerden ayırmaktır. Karantina, bir kişinin hasta olduğunu veya semptom hissetmeden virüs bulaşıp bulaşmadığını bilmeden önce ortaya çıkabilecek hastalığın yayılmasını önlemeye yardımcı olur. Karantinadaki insanlar evde kalmalı, kendilerini diğerlerinden ayırmalı, sağlıklarını izlemeli ve sağlık kuruluşlarının talimatlarını takip etmelidir. İzolasyon; virüs bulaşmış insanları yani COVID-19 hastalarını ve semptomları olmayan kişileri enfekte olmayan insanlardan ayırmak için kullanılır. İzole edilmiş kişiler, başka insanların etrafında olmaları güvenli olana kadar evde kalmalıdır. Hasta veya enfekte olan herkes evde belirli bir "hasta odasında" kalarak ve ayrı bir banyo (varsa) kullanarak diğerlerinden ayrılmalıdır. Hem karantina hem izolasyon; toplumu korumak için insanları ayırır, COVID-19'un daha fazla yayılmasını sinırlandirmaya yardımcı olur, sağlık otoriteleri tarafından istenebileceği gibi gönüllü olarak da yapılabilir. Kişi COVID-19'un yayıldığı veya yayılabileceği bir toplulukta yaşıyorsa sağlığını yakından izlemeli ve hastalık semptomlarına karşı dikkatli olmalıdır. Semptomlar gelişirse vücut ısısının ölçülmesi, sosyal mesafenin korunması ve kalabalık ortamlardan kaçınması gerekmektedir. Kişi kendini sağlıklı hissediyorsa ve son bir hafta içinde COVID-19 tanısı olan bir kişi ile temasta bulunduysa, kendini evde karantinaya almalı ve sağlık durumunu yakından izlemelidir. Son maruziyetten sonra 14 gün kadar evde kalmalı, günde iki kez vücut ısısını kontrol etmeli ve COVID-19 belirtileri açısından gözlemeli, mümkünse COVID-19 hastalığına yakalanma riski daha yüksek olan kişilerden uzak durmalıdır. Eğer kişiye COVID-19 tanısı konduysa veya test sonuçlarını bekliyorsa ya da COVID-19 semptomları varsa evde kalarak izolasyon uygulamalı ve kendini diğer kişilerden ayırmalıdır. Eğer evde başka insanlarla ya da hayvanlarla birlikte yaşıyorsa, evde kendine özel bir odada kalması, hem insanlardan hem de hayvanlardan uzak durması ve mümkünse ayrı banyo kullanması gerekmektedir. ${ }^{22}$ Son zamanlarda başka bir ülkeden uçak, gemi ya da tekne ile yolculuk yaptıysa 14 gün boyunca evde kalması, işe ya da okula gitmemesi, sosyal mesafeyi koruması, toplu taşıma veya taksiye binmemesi ve sağlık durumunu izlemesi önerilmektedir., ${ }^{4,23}$ Kişi seyahatten döndükten sonraki 14 gün içinde ateş veya öksürük ile hastalanırsa; evde kalması, başkalarıyla temastan kaçınması, COVID-19 olabileceği; çoğu insanın evde tıbbi bakım olmadan iyileşebileceği, nefes almakta zorluk çekiyorsa veya belirtilerden endişe ediyorsa bir sağlık uzmanını araması veya mesaj göndermesi, onlara son seyahati ve belirtileri hakkında bilgi vermesi gerektiği açıklanır. Bir hekime veya acil servise gitmeden önce arayıp bilgi vermesi, diyaliz gibi başka nedenlerle tıbbi bakım alması gerekiyorsa hekimini araması ve son seyahati hakkında bilgilendirme yapması gerektiği konusunda bilgi verilir. ${ }^{23}$

\section{Ev izolasyonunun sonlandırılması}

COVID-19 tanısı konan veya semptomları olan kişiler; evde veya hastane dışında başka bir yerde iyileşiyorsa, ateş düşürücü ilaç kullanmadan en az 72 saat ateşleri yükselmediyse (ateşsiz üç tam gün), öksürük veya nefes darlığ1 
gibi diğer belirtiler düzeldiyse ve belirtileri ilk ortaya çıktığ günden bu yana en az 7 gün geçtiyse izole odasından ya da ev izolasyonundan çıkabilirler. ${ }^{19}$

COVID-19 semptomları olmayan, ancak testi pozitif olan kişiler; evde ya da hastane ortamı dışında bir yerde kendi kendine izolasyona alınırlar. Bu kişilerin evdeki izole odalarından çıkabilmeleri için ilk pozitif testinin üzerinden en az 7 gün geçmiş olması ve testten bu yana hiç öksürük olmaması ya da nefes darlığı yaşamaması gerekir.

İzolasyon sonlansa dahi bu kişilerin diğer insanlarla arasındaki sosyal mesafeyi koruması, ev ortamı da dahil olmak üzere yanında başka insanlar olduğunda ağız ve burnunu koruyan maske takması gerekmektedir. Herkesin evden dışarı çıkarken maske takması ve sosyal mesafeyi koruması son derece önemlidir. Bu konuda bakanlık tarafından sunulan kılavuzların kullanımı önerilmektedir. Ancak sağlık kuruluşlarının onayı ile izolasyon sonlandırılacak olup, bu kararda yerel özellikler ön plana çıkabilir. ${ }^{4,19}$

\section{Kendi kendine bakım}

Hasta olan kişinin kendi bakımına dikkat etmesi de önemli bir konu olup, bireyin bu konuda bilgilendirilmesi gerekmektedir. Hasta olan kişi mümkün olduğunca dinlenmeli, yavaş yavaş her gün daha fazlasını yapmaya başlamalıdır. Taze sebze ve meyve yiyerek, yeterli protein ve sıvı alarak dengeli beslemesi önemlidir. Ateşi yükseldiğinde, vücudunda ağrı hissettiğinde, öksürdüğünde veya baş ağrısı olduğunda hekimi tarafından verilen ilaçları alması gerektiği açıklanmalıdır. Kişiye mukusun incelmesini ve öksürürken daha rahat çıkmasını sağlamak için bol sıvı alması önerilmelidir. Su, meyve suyu ve et suyu gibi içeceklerin da sıvı almasına yardımcı olacağı açıklanmalıdır. Boğaz ağrısı varsa ılık tuzlu su ile gargara yaparak boğaz ağrısını yatıştırabileceği, bunun için 1 su bardağı ılık suya 1 çay kaşığı tuz ekleyerek tuzlu su yapabileceği, büyük çocukların ve yetişkinlerin boğaz pastilleri, buz parçaları veya boğaz ağrısı spreyi de kullanabilecekleri belirtilir. Evlerindeki hava nemini artırmak için bir nemlendirici veya buharlaştırıcı kullanabileceklerini, bunun nefes almayı kolaylaştıracağını ve öksürüğü azaltmaya yardımcı olacağını açıklamak gerekir. Ayrıca burun tıkanıklığını gidermek için salin burun damlası kullanabileceği söylenmelidir. Tahrişi azaltmak için burun deliklerinin dışına yumuşatıcı kremler sürebilecekleri iletilir. Sigara ve purolarda bulunan nikotin ve diğer kimyasalların hastalık belirtilerini daha da kötüleştireceği için bu ürünleri kullanmaması vurgulanmalıdır. ${ }^{18,19}$ Ayrıca her bireyin nefes almada zorluk, göğüste kalıcı ağrı veya baskı, bilinç bulanıklığı ya da uykuya eğilim, dudakları veya yüzü mavimsi olduğunda durumun acil olduğunu ve mutlaka sağlık kuruluşuna başvurmaları gerektiğini bilmelidir.

\section{Evcil hayvanlarla temas}

Koronavirüsler (CoV’ler); evcil ve vahşi hayvanlarda, kümes hayvanlarında ve kemirgenlerde hafif ila şiddetli derecede enterik, solunum ve sistemik hastalıklara, ayrıca insanlarda soğuk algınlığı veya zatürreye yol açarak geniş bir yelpazede hastalıklara neden olmaktadır ${ }^{24}$. Shi ve arkadaşları (2020) kedilerin ve gelinciklerin deneysel olarak SARS-CoV-2 ile enfekte olduğunu; ancak köpek, domuz, tavuk ve ördeklerin enfekte olmadığını belirlemiştir. $\mathrm{Bu}$ çalışmada tek bir denekte kedilerin SARSCoV-2'yi solunum yoluyla yaydığ 1 ve diğer kedilerin enfekte olabileceğini iddia etmişlerdir ${ }^{24}$. Bulaşıcı hastalık uzmanları ile çok sayıda uluslararası insan sağlığı (CDC ve WHO) ve evcil hayvan sağlığ1 örgütleri (OIE-World Organisation for Animal Health), COVID-19'un evcil hayvanlardan insanlara geçtiğine dair herhangi bir kanıt olmadığını doğrulamaktadır. Evcil hayvanların COVID-19 ile hastalandığına ilişkin bir rapor olmamasına rağmen virüs hakkında daha fazla bilgi elde edilinceye kadar çok dikkatli olunması ve COVID-19 ile hasta olan kişilerin evcil hayvanlarla temasinın sinırlandırılması tavsiye edilmektedir. ${ }^{25}$

\section{Stres ve Başetme}

COVID-19 pandemisi insanlar için stresli bir durum olabilir. Bu nedenle bireylerin yaşadığı stres düzeyinin belirlenmesi ve bireye özgü yöntemlerin belirlenerek etkili bir 
şekilde başa çıkmasının sağlanması önemlidir. Hastalık hakkındaki korku ve endişe, yetişkinlerin ve çocukların çok güçlü duygusal değişiklikler yaşamalarına neden olabilir. Özellikle bireyler kendi sağlığı ve sevdiklerinin sağlığı hakkında korku ve endişeye kapılabilir. Bu duygu değişikliği bireylerin uyku ve beslenme alışkanlıklarında değişime, uyumada ya da konsantre olmada güçlük yaşamasına, mevcut ise kronik sağlık sorunlarının ve akıl sağlığının kötüleşmesine, alkol ve sigara kullanımında artışa neden olabilir.

Stresle başa çıkmak ise hasta kişiyi, önem verdiği insanları ve içinde yaşadığı sosyal çevreyi güçlendirir. Sosyal medya da dahil olmak üzere haberleri izlemek, okumak veya dinlemek için mola vermek stresle başa çıkma yöntemlerinin başında gelmektedir. Bireyin kendisine iyi bakabilmesi ve akıl sağlığını koruyabilmesi için çeşitli yöntemlerin kullanımı önerilmektedir. Derin soluk alıp verme, meditasyon, sağlıklı ve dengeli beslenme, düzenli egzersiz yapma, iyi uyuma, alkol ve sigara kullanımından kaçınma, gevşemek için zaman ayırma ve hoşuna giden aktiviteler yapma, başkalarıyla iletişim kurarak endişeleri ve nasıl hissettiği konusunda güvendiği insanlarla konuşma gibi aktiviteleri yaparak bireyin kendisine bakabileceği belirtilmiştir. $\mathrm{Bu}$ süreçte akıl sağlığının da korunması önemlidir. Stres üst üste birkaç gün boyunca bireyin günlük aktivitelerine engel oluyorsa sağlık uzmanını araması önerilmektedir. Önceden var olan zihinsel sağlık durumları olan insanlar tedavilerine devam etmeli ve yeni veya kötüleşen semptomların farkında olmalıdır.

Çocukların pandemi sürecinde yaşadığg stresin üstesinden gelebilmesi için ne yapılması gerektiği konusunda ebeveynlere destek sağlanmalıdır. Çocuklar ve gençler, kısmen, etraflarındaki yetişkinlerden gördükleri şeylere tepki verirler. Ebeveynler ve bakıcılar COVID-19 ile sakin ve güvenli bir şekilde başa çıktıklarında, çocuklar için en iyi desteği sağlayabilirler. Ebeveynler kendilerini ne kadar iyi hazırlarsa, özellikle başta çocuklar olmak üzere çevrelerindeki diğer kişilere daha güven verici olabilirler. Ailenin ço- cuğundaki davranış değişikliklerini izlemesi önemli olup küçük çocuklarda aşırı ağlama veya öfke, tuvalet kazaları veya yatak ıslatma, aşırı endişe ve üzüntü, sağlıksız beslenme ve uyku alışkanlıkları, gençlerde öfkeli davranışlar, okul performansında düşme ve okula gitmek istememe, dikkat ve konsantrasyonda zorluk, geçmişte sevdiği aktiviteleri yapmak istememesi, açıklanamayan baş veya vücut ağrıları, alkol ve sigara kullanımı gibi davranışların izlenmesi önerilmektedir.

Çocukları destekleme yolları çok çeşitli olabilir. Ebeveynlere pandemi durumunda çocuklarını desteklemek için aşağıdaki önerilere uyması konusunda bilgilendirme yapilmalidir.

- Çocuk/çocuklar ile COVID-19 salgını hakkında konuşmak onları rahatlatabilir.

- Çocuğun sorularının yanıtlanması ve COVID-19 salgını ile ilgili gerçeklerin onun anlayabileceği şekilde anlatılması gerekmektedir.

- Ebeveynin çocuğuna güvende olduğu konusunda moral vermesi ve rahatlatması diğer önemli olan bir unsurdur. Çocuklara kendilerini üzgün hissetmelerinin normal olduğunu söylemek gerekir. Bu stresli durumla nasıl başa çıkacaklarını öğrenebilmeleri için ebeveynin kendi stresiyle nasıl başa çıktığını çocuğuyla paylaşması önemlidir.

- Aile üyelerinin sosyal medya da dahil olmak üzere salgın ile ilgili haberlere ulaşmasını sınırlandırmak yararlı olacaktır. Çünkü çocuklar duyduklarını yanlış yorumlayabilir ve anlamadıkları bir şeyden korkabilirler.

- Düzenli rutinlere ayak uydurmaya çalışmak, okullar kapalı iken öğrenme aktiviteleri, rahatlatıcı veya eğlenceli aktiviteler için bir program oluşturmak ailenin sorumluluğundadır.

- Çocuklara rol model olmak son derece önemlidir. Ailedeki yetişkin bireylerin mola vermesi, bolca uyuyup dinlenmesi, egzersiz yapması, iyi beslenmesi, arkadaşları ve aile üyeleriyle iletişim kurması çocuklara iyi bir rol model olmada öncülük yapabilir ${ }^{14}$. 


\section{SONUÇ}

Korona virüs enfeksiyonu insandan insana yakın temas s1rasında hava yolu damlacıkları yoluyla geçmektedir. Özellikle öksürme, hapşırma ya da öpüşme büyük risk oluşturduğu için enfekte eş ya da aile üyeleri bu aktivitelerden kaçınmalıdır. Enfeksiyondan şüphelenildiğinde temastan kaçınılması ve enfekte kişilerin izole edilmesi gerekmektedir. Virüs hayvanlardan da bulaşabileceği için hayvan pazarlarını ziyaret etmekten, hayvanlara ve dışkılarına temas etmekten kaçınılmalıdır. Henüz aşısı ve spesifik tedavisi yoktur. Bundan dolayı sosyal yaşamda mesafe koymak, maske takmak, elleri su ve sabunla yıkamak, herhangi bir enfeksiyon ya da hastalık belirtileri ortaya çıktığında hekime başvurmak hayat kurtarıcıdır. Hemşirelerin eğitici rolleri gereği korona virüsün bulaşması, korunma yöntemleri, COVID-19 şüphesi olan ya da tanısı doğrulanmış kişilerin evde yönetimi ve dikkat edilecek konular hakkında hastalara ve aile üyelerine bilgi vermesi gerekmektedir.

\section{Çalışmayı maddi olarak destekleyen kişi/kuruluş yoktur ve yazarın herhangi bir çıar dayalı ilişkisi yoktur.}


J Biotechnol and Strategic Health Res. 2020;4(2):78-88

BİLİK, Hasta ve Yakınlarının Eğitiminde COVID-19: Hemşireler Ne Anlatmalı?

\section{Kaynaklar}

1. Xiao Y, Torok ME. Taking the right measures to control COVID-19. Lancet Infect Dis. 2020;20(5):523-524. doi:10.1016/S1473-3099(20)30152-3.

2. WHO. Coronavirus disease 2019 (COVID-19) situation report 29. Jan 31, 2020. https:// www.who.int/docs/default-source/coronaviruse/situation-reports/20200218-sitrep-29-covid-19.pdf?sfvrsn=6262de9e_2 (accessed Feb 29, 2020), (05.04.2020)

3. Coronavirus disease (COVID-19) Situation Report - 114 Data as received by WHO from national authorities by 10:00 CEST, 13 May 2020. https://www.who.int/docs/default-source/coronaviruse/situation-reports/20200513-covid-19-sitrep-114.pdf?sfvrsn=17ebbbe_4, (13.05.2020)

4. T.C. Sağllk Bakanlĭgı Halk Sağllğı Genel Müdürlüğü. COVID-19 (SARS-CoV-2 Enfeksiyonu) Rehberi, 14 Nisan 2020, Ankara. https://covid19bilgi.saglik.gov.tr/depo/rehberler/ COVID-19_Rehberi.pdf, (16.04.2020)

5. Özözen Șahin E, Köroğlu M. SARS-CoV-2; Virüsün Çevresel Özellikleri. J Biotechinol \& Strategic Health Res. 2020; 4: 55-64.

6. Karaca B. Erişsin Yaş Grubunda COVID-19 Klinik Bulguları. J Biotechinol \& Strategic Health Res. 2020; 4: 85-90.

7. Giacomelli A, Pezzati L, Conti F, et al. Self-reported olfactory and taste disorders in SARSCoV-2 patients: a cross-sectional study [published online ahead of print, $2020 \mathrm{Mar} 26$ ]. Clin Infect Dis. 2020;ciaa330. doi:10.1093/cid/ciaa330.

8. Guan WJ, Ni ZY, Hu Y, et al. Clinical Characteristics of Coronavirus Disease 2019 in China. N Engl J Med 2020;382:1708-20. DOI: 10.1056/NEJMoa2002032.

9. Sener A. COVID-19 (SARS Cov-2) Tedavisi. Journal of Biotechnology and Strategic Health Research. 2020; 4: 104-97.

10. Tang G, Kam Ming Chan A. Perioperative management of suspected/ confirmed cases of COVID-19. General Anaesthesia Tutorial 421, Published 6 April 2020; 1-13. https://www. $w f s a h q . o r g / c o m p o n e n t s / c o m \_v i r t u a l \_l i b r a r y / m e d i a / 1 c 4 e c 5 c 64 b 9 a a a c f 7 c 47 f 76 a 61 \mathrm{fb} 6 e$ dc-atow-422-01.pdf, (01.05.2020)

11. World Health Organization. Home care for patients with COVID-19 presenting with mild symptoms and management of their contacts. Interim guidance 17 March 2020. https:// www.who.int/publications-detail/home-care-for-patients-with-suspected-novel-coronavirus-(ncov)-infection-presenting-with-mild-symptoms-and-management-of-contacts, (02.04.2020).

12. Centers for Disease Control and Prevention. Coronavirus Disease 2019 (COVID-19). How to Protect Yourself \& Others. https://www.cdc.gov/coronavirus/2019-ncov/prevent-getting-sick/prevention.html, (10.05.2020).

13. Centers for Disease Control and Prevention. Coronavirus Disease 2019 (COVID-19). Detailed Disinfection Guidance. Interim Recommendations for U.S. Households with Suspected or Confirmed Coronavirus Disease 2019 (COVID-19). https://www.cdc.gov/ coronavirus/2019-ncov/prevent-getting-sick/cleaning-disinfection.html?CDC_AA_refVal $=$ https\%3A\%2F\%2Fwww.cdc.gov\%2Fcoronavirus\%2F2019-ncov\%2Fprepare\%2Fcleaning-disinfection.html, (23.04.2020).
14. Centers for Disease Control and Prevention. Coronavirus Disease 2019 (COVID-19). Interim Infection Prevention and Control Recommendations for Patients with Suspected or Confirmed Coronavirus Disease 2019 (COVID-19) in Healthcare Settings. Update April 13, 2020. https://www.cdc.gov/coronavirus/2019-ncov/hcp/infection-control-recommendations.html?CDC_AA_refVal=https\%3A\%2F\%2Fwww.cdc.gov\%2Fcoronavirus\%2F2019-ncov\%2Finfection-control\%2Fcontrol-recommendations.html, (13.04.2020)

15. Center of Disease Control (CDC). Caring for Someone Sick at Home or other non-healthcare settings. https://www.cdc.gov/coronavirus/2019-ncov/if-you-are-sick/care-for-someone. html, (24.04.2020).

16. Kumar D, Malviya R, Kumar Sharma P. Corona Virus: A Review of COVID-19. EJMO. 2020; 4(1): 8-25

17. Discharge Instructions for Patients Going Home With Suspected COVID-19 Who Are Awaiting Testing Results (As of March 14, 2020, 7:00PM. https://www.mountsinai.org/ files/MSHealth/Assets/HS/About/Coronavirus/PUI_Discharge-to-Home-Instructions_COVID19_as-of-March-14-2020-700PM.pdf, (11.05.2020)

18. NewYork-Presbyterian. Discharge Instructions-Patients with Confirmed or Suspected COVID-19.https://www.cuimc.columbia.edu/file/44634/download?token=3KC-zie9, (12.05.2020).

19. Center of Disease Control (CDC). Caring for Someone Sick at Home or other non-healthcare settings. https://www.cdc.gov/coronavirus/2019-ncov/if-you-are-sick/care-for-someone. html, (24.04.2020)

20. Lu J, Gu J, Li K, et al. COVID-19 outbreak associated with air conditioning in restaurant, Guangzhou, China, 2020. Emerg Infect Dis. 2020 Jul [date cited]. https://doi.org/10.3201/ eid2607.200764

21. Center of Disease Control (CDC). Coronavirus Disease 2019 (COVID-19). Cleaning And Disinfecting Your Home Everyday Steps and Extra Steps When Someone. https:// www.cdc.gov/coronavirus/2019-ncov/prevent-getting-sick/disinfecting-your-home.html, (30.04.2020).

22. Center of Disease Control (CDC). Coronavirus Disease 2019 (COVID-19). Quarantine and Isolation. https://www.cdc.gov/coronavirus/2019-ncov/if-you-are-sick/quarantine-isolation.html, (12.05.2020).

23. Center of Disease Control (CDC). Coronavirus Disease 2019 (COVID-19). Returning from International Travel. https://www.cdc.gov/coronavirus/2019-ncov/travelers/after-travel-precautions.html, (12.05.2020).

24. Shi J, Wen Z, Zhong G, et al. Susceptibility of ferrets, cats, dogs, and other domesticated animals to SARS-coronavirus 2 [published online ahead of print, 2020 Apr 8]. Science. 2020;eabb7015. doi:10.1126/science.abb7015

25. Hasöksüz M, Kiliç S, Saraç F. Coronaviruses and SARS-COV-2. Turk J Med Sci. 2020;50(SI1):549-556. Published 2020 Apr 21. doi:10.3906/sag-2004-127 